\title{
Prevention and Control of Food Spoilage: An Overview
}

\author{
Megha Sherawat*1, Ravi Kant Rahi'2, Varsha Gupta ${ }^{3}$, Deepesh \\ Neelam $^{4}$ and Devki Sain 5 \\ 1Under Graduate Student, ${ }^{2}$ Assistant Professor, ${ }^{3}$ Associate Professor \& Head, \\ ${ }^{4}$ Assistant Professor, ${ }^{5}$ Assistant Professor, Department of Microbiology, \\ JECRC University, Jaipur, Rajasthan, India.
}

Received: 18 Oct 2020 / Accepted: 16 Nov 2020/ Published online: 01 Jan 2021 *Corresponding Author Email: meghasherawat555@gmail.com

\begin{abstract}
We all know about food spoilage which is a very common thing nowadays. In this review, we will explore the main spore-forming microorganisms that involved in the spoilage of various food products. Food products are very rich in nutrient, that why most of the microbes are able to grow in it and cause food poisoning in the humans. There are several microbes that contaminate the food product like fungi, bacteria, yeast and insects. We know about food spoilage and it is also a threat to human health in all over the world. When we talk about food products, first is bakery products that are commonly used in everyday life in the world. But we know that these products are spoiled by the bacteria species. There are several factors that causes the food spoilage such as temperature, $\mathrm{pH}$, culinary practices, physicochemical characteristics etc. The yeast population has high concentration in fresh fruits and vegetables rather than other food products. It is the raw material that contaminates the food at the time of manufacturing. It is the main mode where contamination occurs in the food products. And it releases the lytic enzymes (lipase, proteases) and utilizes herbal acid.
\end{abstract}

\section{Keywords}

Contamination; Food spoilage; Human health; pH; Temperature.

\section{INTRODUCTION:}

Food preservative additives are natural or synthetic substances which degrades the microbes that causes the microbial growth and enzymes activity in food (Ribes et al., 2018). The current overview about the use of natural agents for preservation are isolated from some plants and microorganisms as they help in the preservation and longtime stored food products from the spoilage(Sharif et al.,2017).
Nowadays all the food industries and Laboratories are using additive natural compounds in the food product to preserve the food for long time and make it healthy for human health (Hernabdez et al., 2018). And the research is also focused to develop the safe food product and innovation that meets the consumer acceptable synthetic preservative. (Ekpenyong et al. 2017) for this, new techniques and applications for natural products have been used. 
In these techniques, it uses essential oils which are obtained from the plants that have potential to prevent the food from spoilage. In these oils mostly used oil is Cymbopogon citrates (lemongrass) .It is essential in food preservation (Ekpenyoung et al., 2017). We also consider coriander herb as it is widely used in medicines, pharmacy, and food industry. Coriander is also used to prevent food from spoilage. It does anti-microbial activity against the fungi, bacteria, and yeast (Silva et al., 2017).

Spices: Spices are also used as preservatives; they are that part of plant which are used in the preservation and medicines due to their properties. Spices that are used in preservation are cumin, clove seeds and cinnamon, they have more antioxidant and antimicrobial properties due to their main compound as compared to others (Liu et al., 2017). These spices have been potential to prevent food products from contamination. It provides the beneficial effect like antioxidant activity levels that compatible to regular chemical compounds used in the products (Elizebath et al., 2017).

Herbs: The term "Herb" is referred as leaf or spice, which belongs to sources of plant which used for prevention and treatment of its properties. It have the high bioactivity properties (Kurup and Deotale, 2020). Herbs are used for food and medicinal purposes form many centuries. Nowadays many secondary compound are produced by the plants which used in the field of industry (inhibit foodborne bacteria) and medical (Leja and Katarzyna, 2016). There have various properties associated with products like anti- inflammatory, antioxidants and gluco-regulatory that potential to treat common health problems. Eg. (Phenolic compound) which extract from green leaves of plant (Paterio and Dominguez, 2020).

\section{METHODS OF PREVENTION:}

There are several methods that are used in preventing food from contamination. Researchers are totally focused on techniques and methods to prevent contamination of that food products which are used in everyday life (Ekpenyong et al., 2017). Classification of food preservation and processing methods are shown in Fig. 1. 


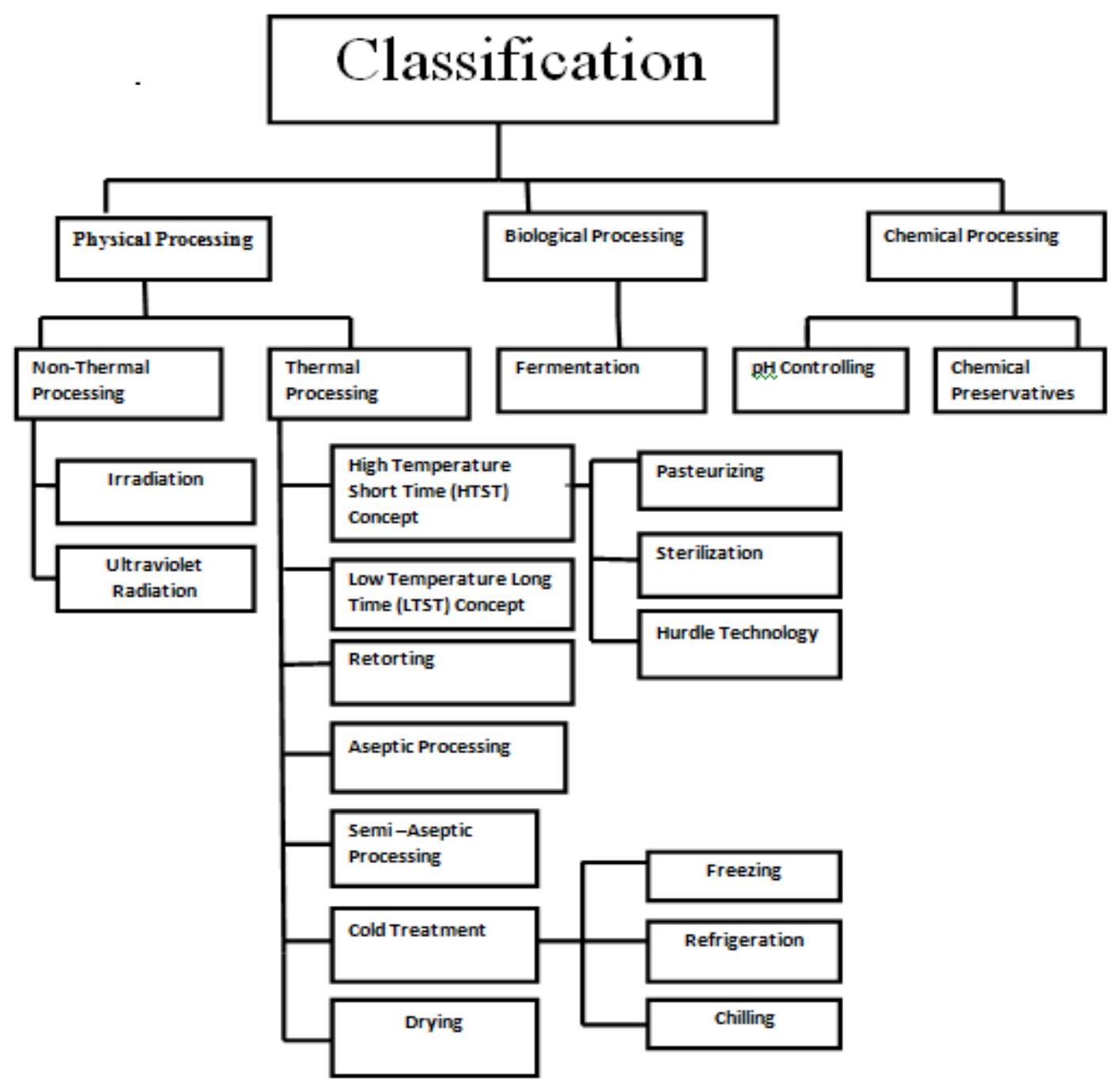

Fig.1 Classification of food preservation and processing methods (Sadat \& Uddan, 2017)

\subsection{Physical Methods}

There are several physical methods uses to control the spoilage of food. Growth and multiplication of microbes are influence by temperature, radiation, water activity and air (Zentralbl, 1985).

\subsubsection{Canning:-}

It is the most common and widely used method for prevention of food spoilage. This method involves some easy steps for sterilization of food for packaging. For this air tight containers (plastic, glassware, and stainless metal) are used. Then after this air tight seal the containers to prevent food from contamination, after that heat treatment is given to kill the bacteria and spores do not grow in the containers. Then immediately the containers are cooled down at $38^{\circ} \mathrm{C}$ temperature it reduces the effect of heat on flavour, texture and quality of products. (Ramesh, 2007). This principle is also applied in another method that is, drying. Drying is the process by which so much water is extracted from the products that reduce the humidity present in the product and not allow the microbes to grow (Niakousari and Grenier, 2018).

\subsubsection{Drying:-}

Drying is the dehydration process in which water/moisture present in the product is reduced. As moisture is one of the reasons due to which microbes grow in food products. So drying is widely used for moisture reduction (Sharif et al., 2017). One traditional form of dried food is quanta; it is the sliced meat which hung in the air for dry (Niakousari and Grenier, 2018).

\subsubsection{Fermentation:-}

Fermentation is the process in which oxidation of carbohydrates takes place that produces the acid and alcohol. It is the most widely and old method used for preservation of food. Some foods products are preserved by fermentation process like vinegar, milk products, in drinks beer, wines and pickles are also preserved by fermentation (acid solution, or vinegar)( Sharif et al., 2017).

\subsection{Chemical Methods}


Chemical method has been classifying chemical incorporation into the food preservation and additives purpose. In traditional method of preservation some household substances like sugar, salt, and spices, wood-smoke are used.

\subsubsection{Sugaring:-}

Sugaring is the process in which sugar is used for preservation of food. It works similar to the salt in the removal of moisture. About $65 \%$ concentration of sugar solution is used as preserving agent in the food products. When concentration of solution is lower than microbes can easily grow in the food. Some of the rare microbes can grow and survive at such concentration of $20-25 \%$ of sugar solution which leads to food spoilage (Rawat, 2015).

\subsubsection{Salting:-}

Salting is the addition of salt into food for preservation. The growth of microbes is inhibited by the salt, because it effects on the water drawn out from the bacterial cell, which ultimately leads to the cell death.

\subsubsection{Smoking:-}

It is the oldest method used to improve and preserve the quality of food products. It is most commonly used in the preservation of fish and meat products (Jay, 2000).

It partially preserves the food by drying food surface as it removes the moisture present on the surface. But at present time it is not considered as a valuable method for preservation unlike salting or drying methods.

\subsubsection{By chemical compounds: -}

Benzoic acid: Benzoic acid is an aromatic carboxylic acid, it is naturally found in (plant and animal) tissues (Olmo et al., 2017). It is the first chemical acid which is used in the food preservation method which is approved by FDA in 2000 (Chipley, 2005). It has a wide range of benzoic compounds are present like (benzyol peroxide, alkyl ester, benzoic salts) and its used as antifungal and antimicrobial preserve method (Olmo et al., 2017). Benzoic acid also use in the beauty products and medicines as chemical prevention (Chipley, 2005).

Nisin: It is the natural compound is use in the many food dairy and meat products. It inactive the bacteria pathogen like (Gram positive and Listeria monocytogenes) microbes (Gharsallaoni, 2016). The structure of nisin is made up of 34 amino acid residues, used in the food products as antimicrobial activity (Krivotova, 2016). It is mostly used in the cheese factory to control the growth of Clostridium spp. (Nazia et al., 2017).

Sulphites: Sulphites (Sulphur dioxide) is the part that use to preserve wine with other chemical compound is active and capable for performing antioxidant and antiseptic activity(Picariello 2020).It is the additive compound that use to controlled the spoilage in the food .It is the primary use natural compound(Irwin et al., 2017). Sulphites that is used in the form of sodium dioxide and sodium sulphite. It commonly used in the candies and jams (Maniha et al., 2020). It is used in the dry fruits, vegetables and pickles (Chatterjee and Abraham, 2018).

\section{TECHNOLOGIES TO PREVENT FOOD SPOILAGE: \\ 3.1 Pasteurization}

Nowadays, people demand to consume the natural food products, for this pasteurization is the traditional techniques that use for kill the microbes (Yu et al., 2020). But traditional pasteurization is reduce the quality of food that's why now scientists is used the new techniques non thermal pasteurization for maintain the food quality and nutrition value (Hung et al., 2017). The high pressure pasteurize techniques is used for inhibit the activity of microbes and kill it. The FDA and USDA has approved that this techniques is good for food processing (Wang et al., 2016). HPP is widely used techniques in the food industry such as dairy product, packed fruits and vegetables and also meat products (Huang et al., 2017). Peoples demand that e commerce food safety is risk, for that FSMA is approved, the packing pasteurizing and microwave pasteurization to reduce the risk of spoilage (Tang and Hag et al., 2018). It increased the life shelf of product to stored for long time .It maintain the quality ,flavor and texture of food(Khan et al. 2017).

\subsection{Irradiation}

Irradiation is first used in Germany in 1958, irradiation studied for food safety and public health (Kontchma et al., 2018). It is the feasible technique for safety food for long time, reduce the growth of pathogen and eliminate the spoilage from the food (Elias, 2018). There are three types of radiation is used but commonly use radiation is Gamma rays (Konthechma et al., 2018). Nowadays Gamma irradiation is more effective in kill the red flour beetle (Sileem et al., 2019). It is the non-thermal emerged techniques for making the safe food and maintain the nutrition value (Odueke et al., 2016). This technique is more efficient for give health food products for consumer (Nishihira, 2020). This is the worldwide techniques for decontamination and disinfection of food product; there are two species which come in food poison (E.coli and Listeria monocytogenes in food product (Pineta et al., 2017). In some of cases it used in freezing and fresh products also for long shelf life. (Pedreschi and Maniotti-celis, 2020).

\subsection{Hurdle Technology}


Hurdle technique is used in industry for the production of safe food and maintains the quality, nutrition levels; it is very effective technique for preservation of foods (Singh and Shalini, 2016). It is the chemical treatment to kill the pathogen of bacteria in the food products (Francois and Ngnitcho, 2017). This is the combination of mild technique, it means bio-preservation and modern air packing to reduce the spoilage .there are 7 species that treated with this technique (Wiernaze and Cornet, 2017). At the current time, it is more applied technique for prevention of food from spoilage (Gueuro and Ferrario, 2017). It help in the inhibit the species Salmonella typhinerium that grow in the coconut water (Nino et al., 2018). This method is killing the different pathogen at same time .It highly effective in bio-films, rather than other single chemical disinfectant (Geruro et.al. 2017).

\subsection{Bio-preservation}

This is the technique which is used to increase the time period of food by natural products or controlled antimicrobial activity. Lactic acid bacteria (LAB) are the special organism that used for this purpose (Singh, 2018). LAB is generally used for biopreservation purpose, it produce some substances like organic acid, hydrogen peroxide, acetone, which inhibited the spoilage microbes (Hammami and Ismail, 2019). There are some bio-preservation are used like fermentation, salts, sugars, and herbs for food preservation (Jhandai et al., 2019). Fermentation is used as bio-preservation technique in food spoilage, to safe the food by chemical compound (Grizani and Bulshi, 2020). This method is very attractive and effective for preservation of food (Akbar and Anal, 2016). Peoples highly interest in quality of food and make chemical free and healthy food product (Grizani and Bulushi, 2020).

\section{NEW TECHNIQUES FOR PREVENTION OF FOOD SPOILAGE:}

\subsection{Bioactive food packaging}

It is a new technique is used for the prevention of food from food-spoilage microorganisms. For this used active extracts from agro-industrial sub products (Almond shells, and grape pomace) with antioxidant activity that developed for antimicrobial benefits to bioactive packaging. It is used against food pathogenic bacteria like E.coli, and Salmonella spp. (Moreira \& Gullón et al.2016).

\subsection{Metabolomics}

It is generally a hypothesis generating tool that used for various analytical equipment's to analyze as various metabolites in a given biological sample. It has been successfully applied to different areas of food science. It is used to study the metabolism of food pathogens and spoilage microorganisms in food products (Pinu 2016).

\section{CONCLUSION AND FUTURE PROSPECTIVE:}

In Recent years, the new technologies are developed and use of natural products is increases for prevention of food spoilage in the food products. At that time mostly techniques are innovated to decreases the rate of spoilage in the products. Many chemicals are used to inhibit the growth of food spoilage. Food is the one of the basic component that necessary for the human. A wide variety of techniques have been developed by scientist to give the healthy life to the consumer. A wide range of modern and advanced techniques and continuing researchers will give effort and should continue applied tools to check the all activity of food problems and ensuring the brand and consumer protection. So, looking ahead scientists will focused on more rapid authenticity tools that easily screening in the field of science. More natural resources are used to target the non-target multi amylase platform across the foods.

\section{ACKNOWLEDGMENT:}

All listed author(s) are thankful to JECRC University for providing the related support to compile this work.

\section{REFERENCES:}

[1] Aelenei, P., Rimbu, C. M., Guguianu, E., Dimitriu, G., Aprotosoaie, A. C., Brebu, M., Horhogea, C. E., \& Miron, A. (2019). Coriander essential oil and linalool interactions with antibiotics against Gram-positive and Gram-negative bacteria. Letters in applied microbiology, 68(2), 156-164. https://doi.org/10.11 11/lam.13100

[2] Akbar, A., Ali, I., \& Anal, A. K. (2016). Industrial perspectives of lactic acid bacteria for biopreservation and food safety. J. Anim. Plant Sci, 26, 938-948.

[3] Amit, S.K., Uddin, M.M., Rahman, R. et al. A review on mechanisms and commercial aspects of food preservation and processing. Agric \& Food Secur 6, 51 (2017). https://doi.org/10.1186/s40066-017-0130-8.

[4] Andreevskaya $M$, Jääskeläinen $E$, Johansson $P$, Ylinen A, Paulin L, Björkroth J, Auvinen P. Food SpoilageAssociated Leuconostoc, Lactococcus, and Lactobacillus Species Display Different Survival Strategies in Response to Competition. Appl Environ Microbiol. 2018 Jun 18; 84(13):e00554-18. doi: 10.11 28/AEM.00554-18. PMID: 29678911; PMCID: PMC6007109.

[5] Aziz, M., \& Karboune, S. (2018). Natural antimicrobial/antioxidant agents in meat and poultry products as well as fruits and vegetables: A review. Critical reviews in food science and nutrition, 58(3), 486-511. https://doi.org/10.1080/10408398.2016.11 94256 
[6] Baptista, R. C., Horita, C. N., \& Sant'Ana, A. S. (2020). Natural productswith preservative properties for enhancing the microbiological safety and extending the shelf-life of seafood: A review. Food research international (Ottawa, Ont.), 127, 108762.

[7] Beristaín-Bauza, S., Martínez-Niño, A., RamírezGonzález, A. P., Ávila-Sosa, R., Ruíz-Espinosa, H., RuizLópez, I. I., \& Ochoa-Velasco, C. E. (2018). Inhibition of Salmonella Typhimurium growth in coconut (Cocos nucifera L.) water by hurdle technology. Food Control, 92, 312-318.

[8] Chatterjee, A., \& Abraham, J. (2018). Microbial contamination, prevention, and early detection in food industry. In Microbial Contamination and Food Degradation (pp. 21-47). Academic Press.

[9] Chipley, J. R. (2005). Sodium benzoate and benzoic acid. FOOD SCIENCE AND TECHNOLOGY-NEW YORKMARCEL DEKKER-, 145, 11.

[10] Del Olmo, A., Calzada, J., \& Nuñez, M. (2017). Benzoic acid and its derivatives as naturally occurring compounds in foods and as additives: Uses, exposure, and controversy. Critical reviews in food science and nutrition, 57(14), 3084-3103. https://doi.org/10.10 80/10408398.2015.1087964

[11] Ekpenyong, C. E., \& Akpan, E. E. (2017). Use of Cymbopogon citratus essential oil in food preservation: Recent advances and future perspectives. Critical reviews in food science and nutrition, 57(12), 2541-2559. https://doi.org/10.108 $0 / 10408398.2015 .1016140$

[12] Elias, P. S. (2018). 36. Task Force on Irradiation Processing-Wholesomeness Studies. Food Protection Technology.

[13] Gharsallaoui, A., Oulahal, N., Joly, C., \& Degraeve, P. (2016). Nisin as a Food Preservative: Part 1: Physicochemical Properties, Antimicrobial Activity, and Main Uses. Critical reviews in food science and nutrition, 56(8), 1262-1274. https://doi.org/10.1080/ 10408398.2013.763765

[14] Guerrero, S. N., Ferrario, M., Schenk, M., \& Carrillo, M. G. (2017). Hurdle technology using ultrasound for food preservation. In Ultrasound: advances for food processing and preservation (pp. 39-99). Academic Press.

[15] Guizani, N., Al Bulushi, I. M., \& Mothershaw, A. (2020). Fermentation as a Food Biopreservation Technique. In Handbook of Food Preservation (pp. 261-282). CRC Press.

[16] Hammami, R., Ismail, F., \& Corsetti, A. (2019). "Application of protective cultures and bacteriocins for food biopreservation". Frontiers in microbiology, $10,1561$.

[17] Huang, H. W., Wu, S. J., Lu, J. K., Shyu, Y. T., \& Wang, C. Y. (2017). Current status and future trends of highpressure processing in food industry. Food control, 72, 1-8.

[18] Irwin, S. V., Fisher, P., Graham, E., Malek, A., \& Robidoux, A. (2017). Sulfites inhibit the growth of four species of beneficial gut bacteria at concentrations regarded as safe for food. PLoS One, 12(10), e0186629.
[19] Jessica Elizabeth T, Gassara F, Kouassi AP, Brar SK, Belkacemi K. Spice use in food: Properties and benefits. Crit Rev Food Sci Nutr. 2017 Apr 13; 57(6):1078-1088. doi: 10.1080/10408398.2013.858235. PMID: 26560460.

[20] Jhandai, P., Jadhav, V. J., \& Gupta, R. (2019). Biopreservation of Foods: A Review. European Journal of Nutrition \& Food Safety, 164-174.

[21] Khan, S., Keshavalu, S. G., Amaresh, R. P. M., Badhautiya, S., \& Bhat, S. A. (2017). High Pressure Processing in Food Industry. Bull. Env. Pharmacol. Life Sci, 6, 28-31.

[22] Koutchma, T., Keener, L., \& Kotilainen, H. (2018). Global Harmonization Initiative (GHI) Consensus Document on Food Irradiation. Discordant International Regulations of Food Irradiation are a Public Health Impediment and a Barrier to Global Trade, 1-18.

[23] Krivorotova, T., Cirkovas, A., Maciulyte, S., Staneviciene, R., Budriene, S., Serviene, E., \& Sereikaite, J. (2016). Nisin-loaded pectin nanoparticles for food preservation. Food Hydrocolloids, 54, 49-56.

[24] Kumar, P., Chatli, M. K., Verma, A. K., Mehta, N., Malav, O. P., Kumar, D., \& Sharma, N. (2017). Quality, functionality, and shelf life of fermented meat and meat products: A review. Critical reviews in food science and nutrition, 57(13), 2844-2856.

[25] Kurup, A. H., Deotale, S., Rawson, A., \& Patras, A. (2020). Thermal Herbs and Processing Spices of. Herbs, Spices and Medicinal Plants: Processing, Health Benefits and Safety.

[26] Leja, K. B., \& Czaczyk, K. (2016). The industrial potential of herbs and spices? A mini review. Acta Scientiarum Polonorum Technologia Alimentaria, 15(4), 353-365.

[27] Liu, Q., Meng, X., Li, Y., Zhao, C. N., Tang, G. Y., \& Li, H. B. (2017). Antibacterial and Antifungal Activities of Spices. International journal of molecular sciences, 18(6), 1283. https://doi.org/10.3390/ijms18061283

[28] Maniha, S. M., Tabassum, T., Tabassum, T., Tabassum, N., \& Noor, R. (2020). In vitro antibacterial traits of the commonly used food preservatives and spices in their crude forms. Biomedical and Biotechnology Research Journal (BBRJ), 4(1)

[29] Modern Food Microbiology book by James M Jay, sixth edition (2000) part 3 (page no.89).

[30] Moreira, D., Gullón, B., Gullón, P., Gomes, A., \& Tavaria, F. (2016). Bioactive packaging using antioxidant extracts for the prevention of microbial food-spoilage. Food \& function, 7(7), 3273-3282.

[31] Nazir, F., Salim, R., Yousf, N., BashirM, N. H., \& Hussain, S. Z. (2017). Natural antimicrobials for food preservation. J Pharmacogn Phytochem, 6(6), 207882.

[32] Ngnitcho, P. F. K., Khan, I., Tango, C. N., Hussain, M. S., \& Oh, D. H. (2017). Inactivation of bacterial pathogens on lettuce, sprouts, and spinach using hurdle technology. Innovative Food Science \& Emerging Technologies, 43, 68-76. 
[33] Nishihira, J. (2020). Safety of irradiated food. In Genetically Modified and Irradiated Food (pp. 259267). Academic Press.

[34] Odueke, O. B., Farag, K. W., Baines, R. N., \& Chadd, S. A. (2016). Irradiation applications in dairy products: a review. Food and Bioprocess Technology, 9(5), 751 767.

[35] Pateiro, M. I. R. I. A. N., Domínguez, R. U. B. É. N., Putnik, P. R. E. D. R. A. G., Kovačević, D. B., Barba, F. J., Munekata, P. S., ... \& Lorenzo, J. M. (2020). Herbal Product Development and Characteristics. Herbal Product Development: Formulation and Applications, 205.

[36] Paulus K. Physikalische Konservierung von Lebensmitteln [Physical preservation of food]. Zentralbl Bakteriol Mikrobiol Hyg B. 1985 Feb; 180(23):299-310. German. PMID: 3993259.

[37] Pawlowska AM, Zannini E, Coffey A, Arendt EK. "Green preservatives": combating fungi in the food and feed industry by applying antifungal lactic acid bacteria. Adv Food Nutr Res. 2012; 66:217-38. doi 10.1016/B978-0-12-394597-6.00005-7. PMID: 22909 981

[38] Pedreschi, F., \& Mariotti-Celis, M. S. (2020). Irradiation kills microbes: Can it do anything harmful to the food? In Genetically Modified and Irradiated Food (pp. 233-242). Academic Press.

[39] Picariello, L., Rinaldi, A., Blaiotta, G., Moio, L., Pirozzi, P., \& Gambuti, A. (2020). Effectiveness of chitosan as an alternative to sulfites in red wine production. European Food Research and Technology, 246(9), 1795-1804.

[40] Pinela, J., Antonio, A. L., \& Ferreira, I. C. (2017). Methods combined with irradiation for food preservation. In Food Irradiation Technologies (pp. 237-279).

[41] Pinu, F. R. (2016). Early detection of food pathogens and food spoilage microorganisms: application of metabolomics. Trends in Food Science \& Technology, 54, 213-215.

[42] Ribes, S., Fuentes, A., Talens, P., \& Barat, J. M. (2018). Prevention of fungal spoilage in food products using natural compounds: A review. Critical reviews in food science and nutrition, 58(12), 2002-2016. https://doi.org/10.1080/10408398.2017.1295017

[43] Santos-Sánchez, N. F., Salas-Coronado, R., ValadezBlanco, R., Hernández-Carlos, B., \& GuadarramaMendoza, P. C. (2017). Natural antioxidant extracts as food preservatives. Acta scientiarum polonorum.
Technologia alimentaria, 16(4), 361-370. https://doi. org/10.17306/J.AFS.0530.

[44] Schmidt, M., Zannini, E., Lynch, K. M., \& Arendt, E. K. (2019). Novel approaches for chemical and microbiological shelf life extension of cereal crops. Critical reviews in food science and nutrition, 59(21), 3395-3419. https://doi.org/10.1080/10408398.2018. 1491526

[45] Sileem, T. M., Mohamed, S. A., \& Mahmoud, E. A. (2019). Efficiency of the Gamma Irradiation in Controlling the Red Flour Beetles, Tribolium castaneum Herbst, and Preventing Its Secondary Infestations. Egyptian Academic Journal of Biological Sciences, F. Toxicology \& Pest Control, 11(1), 87-96.

[46] Silva, F., \& Domingues, F. C. (2017). Antimicrobial activity of coriander oil and its effectiveness as food preservative. Critical reviews in food science and nutrition, 57(1), 35-47. https://doi.org/10.1080/1040 8398.2013.847818

[47] Singh, S., \& Shalini, R. (2016). Effect of hurdle technology in food preservation: a review. Critical Reviews in Food Science and Nutrition, 56(4), 641649.

[48] Singh, V. P. (2018). Recent approaches in food biopreservation-a review. Open veterinary journal, 8(1), 104-111.

[49] Tang, J., Hong, Y. K., Inanoglu, S., \& Liu, F. (2018). Microwave pasteurization for ready-to-eat meals. Current Opinion in Food Science, 23, 133-141.

[50] Tubia, I., Prasad, K., Pérez-Lorenzo, E., Abadín, C., Zumárraga, M., Oyanguren, I., Barbero, F., Paredes, J., \& Arana, S. (2018). Beverage spoilage yeast detection methods and control technologies: A review of Brettanomyces. International journal of food microbiology, 283, 65-76. https://doi.org/10.1016/j. ijfoodmicro.2018.06.020

[51] Wang, C. Y., Huang, H. W., Hsu, C. P., \& Yang, B. B. (2016). Recent advances in food processing using high hydrostatic pressure technology. Critical Reviews in Food Science and Nutrition, 56(4), 527-540.

[52] Wiernasz, N., Cornet, J., Cardinal, M., Pilet, M. F., Passerini, D., \& Leroi, F. (2017). Lactic acid bacteria selection for biopreservation as a part of hurdle technology approach applied on seafood. Frontiers in Marine Science, 4, 119

[53] Yu, T., Niu, L., \& Iwahashi, H. (2020). High-Pressure Carbon Dioxide Used for Pasteurization in Food Industry. Food Engineering Reviews, 12(3), 364-380. 